
\title{
КОМПЛЕКСНА СИСТЕМА РЕАБІЛІТАЦІї ДЕПРЕСИВНИХ РОЗЛАДІВ
} дивів, досягнення та підтримання найможливішого рівня соціального фрункціонування для конкретного пацієнта, що передбачає після досягнення ремісії продовження терапії, в тому числі з урахуванням резидуальної симптоматики.

Мета дослідження - розробити комплексну диференційовану систему реабілітації депресивних розладів з урахуванням клініко-психопатологічних та патопсихологічних особливостей їх перебігу та стандартів терапії.

Матеріали і методи. Обстежили 122 пацієнтів із депресивними розладами. Із загальної кількості обстежених 40 осіб були із депресивними епізодами (F 32.0, 32.1, 32.2), 44 - із рекурентними депресивні розладами (F 33.0, $33.1,33.2), 38$ пацієнтів - із дистимією (F 34.1). Діагноз депресивних розладів було встановлено з урахуванням критеріїв МКX-10. Для проведення дослідження використовували клініко-психопатологічний, психометричний (шкалу Гамільтона (HDRS), шкалу депресій центра епідеміологічних досліджень (CES-D)), психодіагностичний (методику E. Неіт для визначення провідних копінг-стратегій, методику “Семантичний диференціал часу", “Тест самоактуалізації”) методи.

Результати досліджень та їх обговорення. Система заходів реабілітації включала медико-психіатричну, психотерапевтичну та соціальну складову й охоплювала стабілізувальний та профілактичний етапи терапії. Медико-психіатрична складова реабілітації включала в себе психофрармакотерапію, спрямовану на стабілізацію стану хворих, купірування виражених поведінкових порушень, призначення препарату тривалої терапії. Основними завданнями психотерапевтичної складової реабілітації були: запобігти інвалідизації, розпаду сім'ї, розриву соціальних зв'язків, зберегти соціальне фрункціонування пацієнта, допомогти в подоланні почуття провини, безнадійності, неприязні. Психосоціальна складова реабілітації була спрямована на удосконалення соціальних навичок пацієнта, розширення кола сприйняття і міжособистісного спілкування (вироблення адекватних фрорм поведінки, тренування спілкування і підвищення впевненості в собі). Найефективнішими методами для цієї категорії хворих були групова когнітивно-поведінкова психотерапія, група взаємодопомоги й арт-терапія. При виборі технік когнітивно-поведінкової терапії застосовувався диференційований підхід, що спирався на виділення мішеней психотерапевтичного впливу окремо для депресивних епізодів, рекурентних депресивних розладів та дистимії залежно від вираженості та комбінації порушень у специфічних проблемних зонах.

Висновки. Застосування комплексної дисреренційованої системи реабілітаційних заходів у роботі з пацієнтами з депресивними розладами, які базуються на урахуванні особливостей перебігу сучасних депресивних розладів та спираються на стандарти терапії, дає можливість підвищити ефективність надання допомоги для цієї категорії пацієнтів.

ключові слова: депресивні розлади; реабілітаційні заходи; когнітивно-поведінкова терапія.

ВСтУП Згідно з сучасними поглядами на депресивні розлади, метою реабілітації необхідно вважати попередження рецидивів, досягнення та підтримання найможливішого рівня соціального функціонування для конкретного пацієнта, що передбачає після досягнення ремісії продовження терапії, у тому числі з урахуванням резидуальної симптоматики [1-3]. При цьому необхідно враховувати, що на думку пацієнта, найважливіші критерії ремісії - це наявність ознак хорошого психічного здоров'я, наприклад оптимізм і впевненість у собі, повернення до колишнього, нормального стану і звичайного фрункціонування [4].

Відомо, що процес повернення пацієнтів до преморбідного рівня функціонування займає тривалий час, значно більший, ніж потрібно для редукції депресивної симптоматики. На його швидкість та якість впливають і особистісні характеристики пацієнтів, соціальне оточення, наявність або відсутність психотерапевтичних впливів і реабілітаційних заходів, але одним 3 найзначущих чинників для успішного соціального функціонування $€$ відсутність залишкової депресивної симптоматики в стані ремісії [5]. У свою чергу, відновлення соціального фрункціонування сприяє редукції депресивної симптоматики і покращує якість життя хворих [6].

Метою дослідження було розробити комплексну дисреренційовану систему реабілітації депресивних розладів з урахуванням клініко-психопатологічних та патопсихологічних особливостей їх перебігу та стандартів терапії.

МАТЕРІАЛИ І МЕТОДИ Обстежили 122 пацієнтів із депресивними розладами. Із загальної кількості обстежених 40 осіб були із депресивними епізодами (F 32.0, $32.1,32.2), 44$ - із рекурентними депресивними розлада- ми (F 33.0, 33.1, 33.2), 38 пацієнтів - із дистимією (F 34.1). Діагноз депресивних розладів було встановлено з урахуванням критеріїв MKX-10. Для проведення дослідження використовували клініко-психопатологічний, психометричний (шкалу Гамільтона (HDRS), шкалу депресій центра епідеміологічних досліджень (CES-D)), психодіагностичний (методику E. Неim для визначення провідних копінг-стратегій, методику "Семантичний диференціал часу", "Тест самоактуалізації") методи.

РЕЗУЛЬТАТИ ДОСЛІДЖЕНЬ ТА ЇХ ОБГОВОРЕННЯ Систему засобів реабілітації було побудовано на наступних принципах:

1) доказової медицини з урахуванням сучасних міжнародних рекомендацій;

2) забезпечення наступності етапів медичної допомоги;

3) урахування отриманих клінічних даних про пацієнта, а також існуючих діагностичних і лікувальних можливостей.

Від початку захворювання пацієнт із депресивним розладом потребує активної психологічної підтримки з боку оточення: лікарів, середнього медичного персоналу, членів сім'ї. Психореабілітаційна робота 3 цією категорією хворих планувалася на засадах відкритості й партнерства, формування мотивацій, з встановленням мети, пріоритетів та завдань терапії, обговоренням перспектив лікування.

Реабілітація $є$ необхідною складовою комплексного втручання в загальній структурі психіатричної допомоги. При цьому інтегративний підхід має ряд переваг, оскільки торкається відразу всіх сторін життєдіяльності пацієнтів та їх найближчого оточення. Це вкрай важливо, тому що дозволяє задіяти збережені сторони особистості хворих і створити на цій основі досить високий рівень мотивації до 
позитивних змін, ссрормувати свідоме ставлення до лікування та відповідальність за свою поведінку.

Сучасна реабілітація базується на біопсихосоціальній моделі, що включає наступні складові:

- медико-психіатричну (біологічну);

- психотерапевтичну (психологічну);

- психосоціальну (соціальну).

Медико-психіатрична складова реабілітації включала в себе психофармакотерапію, спрямовану на стабілізацію стану хворих, купірування виражених поведінкових порушень, призначення препарату тривалої терапії.

Крім того, всім пацієнтам надавалися рекомендації щодо заходів немедикаментозної корекції: дотримуватись режиму дня, гігієни сну, засад раціонального харчування, режиму регулярної фрізичної активності.

Основними завданнями психотерапевтичної складової реабілітації були: запобігти інвалідизації, розпаду сім'ї, розриву соціальних зв'язків, зберегти соціальне фрункціонування пацієнта, допомогти в подоланні почуття провини, безнадійності, неприязні. Психотерапевтичне втручання також мало потенціювати антидепресивну дію біологічного методу лікування. При цьому групова психотерапія дозволяла сорокусувати лікувальний вплив на одній із найпроблематичніших сторін існування пацієнта 3 афективним розладом - порушенні міжособистісного спілкування (зокрема шляхом стимулювання емоційності, соціальної активізації і налагодження комунікацій).

Психосоціальна складова реабілітації була спрямована на удосконалення соціальних навичок пацієнта, розширення кола сприйняття і міжособистісного спілкування (вироблення адекватних форм поведінки, тренування спілкування і підвищення впевненості в собі).

Однією з ключових проблем у системі сучасної реабілітації пацієнтів із психічними розладами є стигматизація, що поділяється на культуральну, інституціональну та самостигматизацію. Останній вид стигматизації з постійними думками щодо власної неповноцінності й неможливості стати активним членом суспільства особливо притаманний хворим із депресивними розладами. Наслідком самостигматизаціі $€$ зниження самооцінки та погіршення адаптації і фрункціонування в суспільстві. Саме тому в лікуванні пацієнтів із даною патологією необхідна увага приділялася фрормуванню впевненості в собі та виявленню особистісних ресурсів для подолання труднощів, пов'язаних із соціалізацією.

Не менш важливим пунктом в процесі сучасної реабілітації психічно хворих пацієнтів є зміна підходу від створення "оточення, що найменш обмежує" до "оточення, що найбільш підтримує". Перш за все необхідно сказати, що родичів пацієнтів варто розглядати як союзників у лікуванні. Вони не тільки повинні багато чому навчитися, але й самі часто володіють достатнім обсягом знань та досвіду, що робить істотний внесок у процес реабілітації. Для лікаря родичі можуть бути цінним джерелом інорормації про стан пацієнта, часом вони більше, ніж фрахівці, обізнані про деякі аспекти його захворювання. Часто сім'я виконує роль сполучної ланки між хворим і системою надання психіатричної допомоги.

Залучення сім'ї до бесід із психіатричної освіти - необхідний крок у процесі психосоціальної реабілітації паці$є н$ та. Розуміння основ психології хворого на депресивний розлад, вміння розпізнавати клінічні прояви захворювання, освоєння навичок спілкування 3 хворою людиною в сім'ї дають реальну можливість знизити частоту загострень захворювання і повторних госпіталізацій.
Традиційно етапи терапії поділяють на активне лікування, тривале (стабілізувальне) і підтримувальне (профрілактичне) лікування. Виходячи з визначення, система реабілітаційних заходів охоплювала стабілізувальний та підтримувальний етапи терапії.

Стабілізувальний етап триває не менше 6 місяців для всієї категорії хворих із депресивними розладами і слугує для подолання резидуальної симптоматики, профрілактики раннього рецидиву, повернення повного функціонування та якості життя пацієнта.

Профрілактичне лікування терміном 12 місяців або більше - необхідний етап для пацієнтів із рекурентною депресією та дистимією для підтримання їх повного фрункціонування та якості життя, профрілактики рецидиву.

Оскільки стаціонарне лікування цієї категорії хворих у закладі третинної (високоспеціалізованої) допомоги тривало 24 дні, пацієнти із депресивними розладами потребували диспансерного спостереження (у консультативній або диспансерній групі).

Система медико-соціальної реабілітації депресивних розладів розроблялася з урахуванням фракторів їх фрормування, перебігу та виходу, була комплексною, диференційованою та спрямованою на відновлення соціального функціонування особистості (табл. 1-3).

В етіопатогенезі сучасних депресивних розладів важливу роль відіграють як ендогенні, так й екзогенні (психогенні) чинники. Останні характеризуються переважанням соціально-психологічних впливів та диференційованим значенням у розвитку різних фрорм депресивних розладів: при дистимії екзогенні чинники можуть виступати провідними в розвитку патології згідно з концепцією невротичного розвитку депресії, при депресивних епізодах, рекурентних депресивних розладах та дистимії ендогенного генезу - провокуючими.

При плануванні програм реабілітації ураховувалися такі фрактори, як особистісні характеристики пацієнтів, типи копінг-стратегій, що найчастіше застосовуються, особливості суб'єктивного сприйняття індивідуального часу, які відіграють великого значення у фрормуванні, перебігу та виходу депресивних епізодів. Зокрема, у пацієнтів із депресивними розладами переважали такі дезадаптивні копінги, як "розгубленість", "пасивна кооперація" та "відступ". Структура суб'єктивного сприйняття індивідуального часу характеризувалася негативним сприйняттям теперішнього та майбутнього. Оцінка показників самоактуалізації свідчила про зниження власної відповідальності, негативне ставлення до себе та оточуючих, зниження потреби у спілкуванні та діяльності.

Психосоціальна реабілітація для пацієнтів із депресивними розладами передбачає тренінг когнітивних фуункцій, тренінг вирішення проблем, міжособистісної взаємодії, тренінг комунікативних навичок, тренінг позитивного самосприйняття та впевненої поведінки. Враховуючи вищевикладене, провідним методом психотерапевтичної складової системи реабілітаційних заходів було обрано когнітивно-поведінкову терапію в індивідуальному та груповому варіантах.

При виборі технік когнітивно-поведінкової терапії застосовувався диференційований підхід, що спирався на виділення мішеней психотерапевтичного впливу (за А. Беком) окремо для депресивних епізодів, рекурентних депресивних розладів та дистимії залежно від вираженості та комбінації порушень у специсрічних проблемних зонах (табл. 4). 
Таблиця 1. Система реабілітаційних заходів для пацієнтів із депресивними епізодами

\begin{tabular}{|c|c|}
\hline \multicolumn{2}{|r|}{ Стабілізувальний етап терапії (6 місяців) } \\
\hline Фармакотерапія & $\begin{array}{l}\text { Терапія АД продовжується препаратом та в дозах, якими була досягнута мета етапу активної терапії } \\
\text { та які є оптимальними для досягнення завдань етапу стабілізувальної терапії }\end{array}$ \\
\hline Психотерапія & $\begin{array}{l}\text { Когнітивно-поведінкова терапія (в індивідуальному та груповому фрорматах)*: } \\
\text { - визначення атрибуції; } \\
\text { - альтернативна інтерпретація; } \\
\text { жіндивідуальні заняття - } 40 \text { хв один раз на тиждень, групові заняття - } 90 \text { хв один раз на тиждень } \\
\text { Арт-терапія (в груповому форматі)*: } \\
\text { - вільні теми малювання, ліплення, колажів; } \\
\text { - тематичні малюнки; } \\
\text { - вправи з кольорами } \\
\text { ^групові заняття - } 90 \text { хв один раз на тиждень }\end{array}$ \\
\hline Психоосвіта & $\begin{array}{l}\text { Заходи з пацієнтом та його родиною, спрямовані на розуміння механізмів розвитку патологічного } \\
\text { процесу, зворотності хворобливих проявів, необхідності дотримання терапевтичного режиму та } \\
\text { орієнтації на відновлення соціальних фрункцій (бесіди - один раз на тиждень, групи підтримки - один } \\
\text { раз на } 2 \text { тижні) }\end{array}$ \\
\hline \multicolumn{2}{|c|}{$\begin{array}{l}\text { Призначається за наступних умов: } \\
\text { - депресії у пізньому віці; } \\
\text { - наявної зниженої соціальної адаптації; } \\
\text { - за бажанням самого пацієнта }\end{array}$} \\
\hline Фармакотерапія & $\begin{array}{l}\text { Призначається всім пацієнтам на термін до одного року, а пацієнтам з обтяженим депресією сімейним } \\
\text { анамнезом - більше одного року; при вирішенні питання про відміну АД необхідно забезпечити } \\
\text { поступове зменшення його дози впродовж не менш ніж } 4 \text { тижні (для уникнення синдрому "відміни") }\end{array}$ \\
\hline Психотерапія & $\begin{array}{l}\text { Когнітивно-поведінкова терапія (в груповому форматі)*: } \\
\text { - репетиція контраргументів; } \\
\text { - ресинтез минулого; } \\
\text { - ресинтез сімейних переконань; } \\
\text { - переписування сценарію в уяві } \\
\text { жгрупові заняттяя - } 90 \text { хв } 2 \text { рази на місяць } \\
\text { Арт-терапія (в груповому форматі)*: } \\
\text { - вільні теми малювання, ліплення, колажі; } \\
\text { - тематичні малюнки; } \\
\text { - вправи з кольорами } \\
\text { „групові заняття - } 90 \text { хв } 2 \text { рази на місяць }\end{array}$ \\
\hline Психоосвіта & $\begin{array}{l}\text { Заходи з пацієнтом та його родиною, спрямовані на активацію пацієнта, дотримання рекомендацій } \\
\text { лікаря, залучення родичів до лікування та відновлення якості життя пацієнта (бесіди та групи } \\
\text { підтримки - один раз на місяць) }\end{array}$ \\
\hline
\end{tabular}

Таблиця 2. Система реабілітаційних заходів для пацієнтів із рекурентними депресивними розладами

\begin{tabular}{|c|c|}
\hline \multicolumn{2}{|r|}{ Стабілізувальний етап терапії (6 місяців) } \\
\hline Фармакотерапія & $\begin{array}{l}\text { Терапія АД продовжується препаратом та в дозах, якими була досягнута мета етапу активної терапії } \\
\text { та які є оптимальними для досягнення завдань етапу стабілізувальної терапії }\end{array}$ \\
\hline Психотерапія & 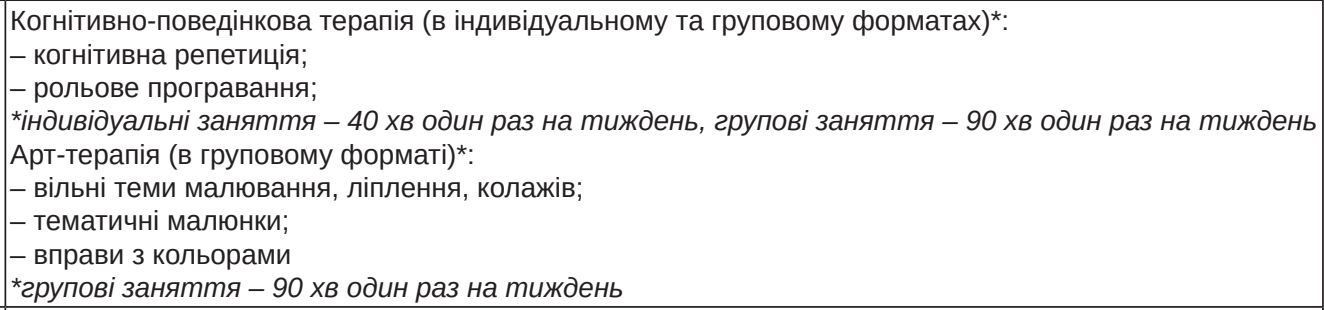 \\
\hline Психоосвіта & $\begin{array}{l}\text { Заходи з пацієнтом та його родиною, спрямовані на розуміння механізмів розвитку патологічного } \\
\text { процесу, зворотності хворобливих проявів, необхідності дотримання терапевтичного режиму та } \\
\text { орієнтації на відновлення соціальних фрункцій (бесіди - один раз на тиждень, групи підтримки - один } \\
\text { раз на } 2 \text { тижні) }\end{array}$ \\
\hline \multicolumn{2}{|r|}{ Профрілактичний етап терапії (12 місяців) } \\
\hline Фармакотерапія & $\begin{array}{l}\text { Призначається всім пацієнтам на термін до одного року, а пацієнтам з трьома та більше епізодами в } \\
\text { минулому та обтяженим депресією сімейним анамнезом - більше одного року; при вирішенні питання } \\
\text { про відміну АД необхідно забезпечити поступове зменшення його дози упродовж не менш ніж } 4 \text { тижні } \\
\text { (для уникнення синдрому “відміни") }\end{array}$ \\
\hline Психотерапія & $\begin{array}{l}\text { Когнітивно-поведінкова терапія (в груповому фрорматі)*: } \\
\text { - визначення очікувань; } \\
\text { - ресинтез минулого; } \\
\text { - ресинтез сімейних переконань; }\end{array}$ \\
\hline
\end{tabular}




\begin{tabular}{|c|c|}
\hline & $\begin{array}{l}\text { - переписування сценарію в уяві } \\
\text { ^групові заняття - } 90 \text { хв } 2 \text { рази на місяць } \\
\text { Арт-терапія (в груповому форматі)*: } \\
\text { - вільні теми малювання, ліплення, колажі; } \\
\text { - тематичні малюнки; } \\
\text { - вправи з кольорами } \\
\text { „групові заняття - } 90 \text { хв } 2 \text { рази на місяць }\end{array}$ \\
\hline Психоосвіта & $\begin{array}{l}\text { Заходи з пацієнтом та його родиною, спрямовані на активацію пацієнта, дотримання рекомендацій } \\
\text { лікаря, залучення родичів до лікування та відновлення якості життя пацієнта (бесіди та групи } \\
\text { підтримки - один раз на місяць) }\end{array}$ \\
\hline
\end{tabular}

Таблиця 3. Система реабілітаційних заходів для пацієнтів із дистимією

\begin{tabular}{|c|c|}
\hline \multicolumn{2}{|r|}{ Стабілізуювальний етап терапії (6 місяців) } \\
\hline Фармакотерапія & $\begin{array}{l}\text { Терапія АД продовжується препаратом та в дозах, якими була досягнута мета етапу активної терапії } \\
\text { та які є оптимальними для досягнення завдань етапу стабілізувальної терапії }\end{array}$ \\
\hline Психотерапія & $\begin{array}{l}\text { Когнітивно-поведінкова терапія (в індивідуальному та груповому форматах)*: } \\
\text { - когнітивна репетиція; } \\
\text { - рольове програвання } \\
\text { жіндивідуальні заняття - } 40 \text { хв один раз на тиждень, групові заняття - } 90 \text { хв один раз на тиждень } \\
\text { Арт-терапія (в груповому форматі)*: } \\
\text { ^групові заняття - } 90 \text { хв один раз на тиждень }\end{array}$ \\
\hline Психоосвіта & $\begin{array}{l}\text { Заходи з пацієнтом та його родиною, спрямовані на розуміння механізмів розвитку патологічного } \\
\text { процесу, зворотності хворобливих проявів, необхідності дотримання терапевтичного режиму та } \\
\text { орієнтації на відновлення соціальних функцій (бесіди - один раз на тиждень, групи підтримки - один } \\
\text { раз на } 2 \text { тижні) }\end{array}$ \\
\hline \multicolumn{2}{|r|}{ Профрілактичний етап терапії (12 місяців) } \\
\hline Фармакотерапія & $\begin{array}{l}\text { Призначається всім пацієнтам на термін до одного року; при вирішенні питання про відміну АД } \\
\text { необхідно забезпечити поступове зменшення його дози впродовж не менш ніж } 4 \text { тижні (для уникнення } \\
\text { синдрому "відміни") }\end{array}$ \\
\hline Психотерапія & $\begin{array}{l}\text { Когнітивно-поведінкова терапія (в груповому фрорматі)*: } \\
\text { - практичні доводи; } \\
\text { - ресинтез минулого; } \\
\text { - ресинтез сімейних переконань; } \\
\text { - переписування сценарію в уяві } \\
\text { „групові занятття - } 90 \text { хв } 2 \text { рази на місяць } \\
\text { Арт-терапія (в груповому форматі)*: } \\
\text { „групові заняттяя - } 90 \text { хв } 2 \text { рази на місяць }\end{array}$ \\
\hline Психоосвіта & $\begin{array}{l}\text { Заходи з пацієнтом та його родиною, спрямовані на активацію пацієнта, дотримання рекомендацій } \\
\text { лікаря, залучення родичів до лікування та відновлення якості життя пацієнта (бесіди та групи } \\
\text { підтримки - один раз на місяць) }\end{array}$ \\
\hline
\end{tabular}

Таблиця 4. Мішені диференційованого психотерапевтичного впливу при депресивних розладах

\begin{tabular}{|l|c|c|}
\hline \multicolumn{1}{|c|}{ Специфічна проблемна зона } & Депресивний епізод & $\begin{array}{c}\text { Рекурентний } \\
\text { депресивний розлад }\end{array}$ \\
\hline $\begin{array}{l}\text { Поведінкові симптоми (пасивність, відірваність від } \\
\text { зовнішнього світу, уникнення) }\end{array}$ & + & ++ \\
\hline Суїцидальні наміри & ++ & ++ \\
\hline Відчуття безнадійності & + & ++ \\
\hline Втрата задоволення & + & ++ \\
\hline $\begin{array}{l}\text { Самозвинувачення, самокритика, } \\
\text { ненависть до себе }\end{array}$ & ++ \\
\hline Душевний біль (тужливий есект) & ++ \\
\hline $\begin{array}{l}\text { Перебільшення внутрішніх вимог до себе, відчуття } \\
\text { завантаженості проблемами }\end{array}$ & ++ \\
\hline
\end{tabular}

Примітки: 1) + - виражені меншою мірою;

2) ++ - виражені більшою мірою.

ВИсновки 1. Аналіз результатів системи реабілітаційних заходів засвідчив суттєву важливість цього виду допомоги в комплексній терапії депресивних розладів. Найесективнішими для цієї категорії хворих методами були групова когнітивно-поведінкова психоте- рапія, група взаємодопомоги й арт-терапія. Так, при роботі з вищезазначеними модулями у більшості випадків пацієнти, на думку лікарів, ставали комунікабельними, більш відкритими, із конструктивною готовністю обговорювати наявні особисті проблеми вже після 3-4 
занять (при збереженні клінічних проявів депресивної симптоматики).

2. Застосування інтегративної системи реабілітаційних підходів у роботі з пацієнтами із депресивними розладами, які базуються на врахуванні особливостей перебігу сучас- них депресивних розладів та спираються на стандарти терапії, дає можливість підвищити ефективність надання допомоги, що сприяє не лише скороченню кількості госпіталізацій та тривалості перебування пацієнта на стаціонарному лікуванні, а й на подовженні періоду ремісії.

\section{СПИСОК ЛІТЕРАТУРИ}

1. Марута Н. А. Восстановление социального фуннцционирования - основная цель терапии депрессии / Н. А. Марута // НейpoNEWS. - 2013. - № 8 (53). - C. 16-19.

2. Psychosocial functioning in patients with treatment-resistant depression after group cognitive behavioral therapy / M. Matsunaga, Y. Okamoto, S. Suzuki [et al.] // BMC Psychiatry. - 2010. doi:10.1186/1471-244X-10-22.

3. Gupta M. Understanding treatment-resistant depression: the complicated relationships among neurocognition, symptoms, and functioning / M. Gupta // A thesis submitted to Department of Psychology in conformity with the requirements for the degree of Masters of Science. - Queen's University, Kingston, Canada, 2011. $-60 \mathrm{p}$.

4. Депресія (легкий, помірний, тяжкий депресивні епізоди без соматичного синдрому або з соматичним синдромом, рекурентний депресивний розлад, дистимія) : уніфікований клінічний протокол первинної, вторинної (спеціалізованої) та третинної (високоспеціалізованої) медичної допомоги, затверджений наказом Міністерства охорони здоров'я України від 25 грудня 2014 p. № 1003.

5. Psychosocial and neurocognitive functioning in unipolar and bipolar depression: a 12-month prospective study / J. Godard, P. Baruch, Grondin S., M. F. Lafleur // Psychiatry Res. - 2012. Vol. 196, No. 1. - P. 145-153.

6. Effect of psychosocial interventions on social functioning in depression and schizophrenia: meta-analysis / M. J. De Silva, S. Cooper, H. L. Li [et al.] // British Journal of Psychiatry. - 2013. - Vol. 202. P. 253-260

Отримано 03.08.18

Електронна адреса для листування: vfedchenko83@ukr.net

\section{(C). Y. Fedchenko} Institute of Neurology, Psychiatry and Narcology of NAMS of Ukraine

\section{COMPLEX SYSTEM OF REHABILITATION OF DEPRESSIVE DISORDERS}

Summary. According to modern views on depression, rehabilitation should be considered a prevention of relapse, achievement and maintenance of the most possible level of social functioning for a particular patient, which implies, after remission, the continuation of therapy, including taking into account residual symptoms.

The aim of the study - to develop a complex differentiated system of rehabilitation of depressive disorders, taking into account clinical and psychopathological and pathopsychological features of their course and standards of therapy.

Materials and Methods. The research used clinical-psychopathological, psychometric (Hamilton scale (HDRS), depression scale of the Center for epidemiological research (CES-D)), psychodiagnostic (E. Heim's method for determining the leading coping strategies, the method "Semantic time differential", "Test self-actualization") methods.

Results and Discussion. The system of rehabilitative measures included a medical-psychiatric, psychotherapeutic and social component and covered the stabilizing and preventive stages of therapy. The medical and psychiatric component of rehabilitation included psychopharmacotherapy, aimed at stabilizing the patients' condition, stopping the expressed behavioral disorders, the appointment of a long-term treatment drug. The main tasks of the psychotherapeutic component of rehabilitation were the prevention of disability, the breakdown of the family, the breakdown of social connections, the preservation of the social functioning of the patient, help in overcoming the feeling of guilt, hopelessness, hostility. The psychosocial component of rehabilitation was aimed at improving the patient's social skills, expanding the range of perception and interpersonal communication (developing adequate forms of behavior, training communication and increasing self-confidence). The most effective methods for this category of patients were group cognitivebehavioral psychotherapy, a group of mutual assistance and art therapy. When choosing a technique of cognitive-behavioral therapy a differentiated approach based on the allocation of the targets of psychotherapeutic effect was used separately for depressive episodes, recurrent depressive disorders and dysthymia, depending on the severity and combination of disturbances in specific problem areas.

Conclusions. The use of a complex differentiated system of rehabilitation measures in the work with patients with depressive disorders, which are based on taking into account the peculiarities of current depressive disorders and based on the standards of therapy, makes it possible to increase the effectiveness of providing assistance to this category of patients.

Key words: depressive disorders; rehabilitation activities; cognitive behavioral therapy. 
ISSN 1681-276Х. ВІСНИК НАУКОВИХ ДОСЛІДЖЕНЬ. 2018. № 3

(СВ. Ю. Федченко

ГУ “Институт неврологии, психиатрии и наркологии НАМН Украины", г. Харьков

\section{КОМПЛЕКСНАЯ СИСТЕМА РЕАБИЛИТАЦИИ ДЕПРЕССИВНЫХ РАССТРОЙСТВ}

Резюме. Согласно современным взглядам на депрессивные расстройства, целью реабилитации следует считать предупреждение рецидивов, достижение и поддержание наиболее возможного уровня социального функционирования для конкретного пациента, что предусматривает продолжение терапии после достижения ремиссии, в том числе с учетом резидуальной симптоматики.

Цель исследования - разработать комплексную дифференцированную систему реабилитации депрессивных расстройств с учетом клинико-психопатологических и патопсихологических особенностей их протекания и стандартов терапии.

Материалы и методы. Обследовали 122 пациентов с депрессивными расстройствами. Из общего количества обследованных 40 человек были с депрессивными эпизодами (F 32.0, 32.1, 32.2), 44 - с рекуррентными депрессивными расстройствами (F 33.0, 33.1, 33.2), 38 пациентов - с дистимией (F 34.1). Диагноз депрессивных расстройств было установлено с учетом критериев МКБ-10. Для проведения исследования использовались клинико-психопатологический, психометрический (шкала Гамильтона (HDRS), шкала депрессии центра эпидемиологических исследований (CES-D)), психодиагностические (методика E. Неim для определения ведущих копинг-стратегий, методика "Семантический диффференциал времени”, "Тест самоактуализации") методы.

Результаты исследований и их обсуждение. Система мер реабилитации включала медико-психиатрическую, психотерапевтическую и социальную составляющую и охватывала стабилизирующий и профилактический этапы терапии. Медикопсихиатрическая составляющая реабилитации включала в себя психофрармакотерапию, направленную на стабилизацию состояния больных, купирование выраженных поведенческих нарушений, назначение препарата длительной терапии. Основными задачами психотерапевтической составляющей реабилитации были: предотвращение инвалидизации, распада семьи, разрыва социальных связей, сохранение социального фрункционирования пациента, помощь в преодолении чувства вины, безнадежности, неприязни. Психосоциальная составляющая реабилитации была направлена на совершенствование социальных навыков пациента, расширение круга восприятия и межличностного общения (выработка адекватных фрорм поведения, тренировка общения и повышения уверенности в себе). Наиболее эффективными для этой категории больных методами были групповая когнитивно-поведенческая психотерапия, группа взаимопомощи и арт-терапия. При выборе техник когнитивно-поведенческой терапии применялся дифференцированный подход, опиравшийся на выделение мишеней психотерапевтического воздействия отдельно для депрессивных эпизодов, рекуррентных депрессивных расстройств и дистимии в зависимости от выраженности и комбинации нарушений в специфических проблемных зонах.

Выводы. Применение комплексной дифференцированной системы реабилитационных мероприятий в работе с пациентами с депрессивными расстройствами, которые основаны на учёте особенностей течения современных депрессивных расстройств и опираются на стандарты терапии, дает возможность повысить эффрективность оказания помощи этой категории пациентов.

Ключевые слова: депрессивные расстройства; реабилитационные мероприятия; когнитивно-поведенческая терапия. 